\title{
Zuiver historisch onderzoek en het evangelie
}

Naar aanleiding van drs. Tj. Baarda, De Betromwharheid van de Evangeliën, Kok, Kampen, 1967, deel 2 van de serie: Cahiers voor de gemeente. Ingenaaid f.4.90).

Wie als drs. Baarda en dr. Augustijn de gemeente bij het geloof wil behouden. zal zich naar mijn mening over deze betuiging van apostolische geloofwardigheid toch nog anders moeten uitspreken dan tot hiertoe is geschied. Want zonder de principiële historische betrouwbaarheid van de evangelien is het. naar mijn overtuiging. bij alle overblijvende spiritualiteit. met het christelijk geloof gedán. Prof. dr. Herman Ridderbos in (ieref. Weekhlad $X X$, 51 (16 Juni 1967).

Gemeente - theologie.

Het was in de oorlogsdagen. ergens in een molern, vrijzinnig dorp in Friesland. Een gealieerde vlieger was aangespoeld. Hij zou op het kerkhof bij het dorpskerkje begraven worden. De hervormde. vrijzinnige dominee zou een toespraak houden. Wat duitsers in de houding bij het graf. Wat toeluisterende dorpelingen voor het hek om het kerkhof. Ik herinner me het trieste gebeuren nog als de dag van gisteren. De dominee sprak over Jezus. die de storm op zee stilde. Hij zei, dat dit maar een verhaal was, dat aanduide, dat Jezus innerlijke rust bracht. Deze Jezus was zo'n groot mens. dat Zijn discipelen hem later Zoon van God hebben genoemd.

Ik was de eerste keer van miljn leven geconfronteerd met wal men wel 'gemeente-theologie' noemt. Jezus had zichzelf niet geopenhaard als de Zoon van God, Joch we zouden hier te maken hebben met een interpretatie door de gemeente. Wat de evangeliën ons berichten, zou niet werkelijk gebeurd zijn. doch de volgelingen van Jezus zouden een en ander opgepoetst hebben on zo de verhalen en titels in dienste van de verkondiging te stellen. De werkelijke geschiedenis zou in dienst van de prediking van de levende Heer vervormd zijn.

We hebben nu in het bockje van drs. Baarda een poging om deze gemeente-theologie te introduceren onder "het gewone volk". Buarda meent. dat het niet houdbaar is. dat de 'evangelien' ons overal werkelijke historische feiten berichten. Wal we daar lezen is enerzijds wel waar. Baarda wil nog wel in Jezus als Heer geloven. Maar anderzijds zijn de berichten toch nict allemaal waar. Als we deze historisch gaan meten, blijkt volgens hem. dat er dissonanten zijn. dingen die niet kloppen, opsieringen. De gemeente is na pasen aan een recreatie. d.w.z. aan een herschepping begonnen. Zij heeft vanuit de opstanding alle mededelingen van het gebeuren rond de rabbi en wonderdoener Jezus nog eens herzien, en toen zelfs de legende in dienst gesteld van haar prediking. Het is -- en deze vergelijking maak ikzelf thans 
met het evangelie gegaan als met de verhalen rondom Greate Pier in Friesland. Er zijn allerlei mythische. legendarische trekken bijgekomen. Men heeft de volksvertelling gedramatiseerd. Het is -- ook hier is de vergelijking weer van mij - als met een historische roman gegaan. De (ontmythologiseerde) kern is echt. Maar er is heel wat omheen gesponnen. Allerlei Woorden van Jezus hebben aanleiding gegeven tot het ontstaan van bepaalde verhalen. Naar aanleiding van profetieën die men als messiaans interpreteerde. heeft men in verhalen correcties, verfraaiingen aangebracht.

In het feit. dat er reeds 4 "evangelien' bestaan. oefent de Schrift volgens Baarda critiek op onze "gangbare" beschouwing. dat alles wat in de evangelien staat, ook werkelijk zo gebeurd is. In onze kunstbeleving mijden we vandaag ook niet meer de dissonant. evenmin in onze compositie-leer. Wij kunnen ons vandaag God voorstellen als een Artist, die de dissonant niet schuwt (blz. 41). Zuiver historisch onderzoek laat uitkomen. dat er onefienheden. dissonanten in de evangelièn zijn. De verschillen in de overlevering laten ons zien, dat ran cen historische hetrouwhaurheid in de onler ons ganhare in geen sprake is (blz. 83). 'De oplossing van die verschillen ligt ergens (! v.d.W.) in de veelkleurige prediking van de oude Gemeente' (blz. 79).

'ER STAAT (iESC'HREVEN' is niet zonder meer volgens Baarda: 'ER IS GESCHIED' of 'ER IS GEZEGD' (blz. 8()). Johannes geeft in zijn 'evangelie' daarom eigenlijk geen cchte Woorden van Jezus weer. doch woorden van de levende en Opgestane. zoals deze creatief of recreaticf door christelijke profeten waren verkondigd (blz. 75). De mógelijkheid daartoe wil Baarda in elk geval openhouden. De redactor van 'Johannes" heeft daarom ook weinig zorgvuldig zijn boek gecomponeerd. Het ging hem niet om het voór-en-ná uit elkaar te houden. daar het voór en ná de opstanding door hem bewust werd door. broken (blz. 75)

Historisch onderzoek laat Jezus zien als een mens. een wonderloende rabbi, die zich keerde tegen het joodse formalisme en in woorden en werken de radicaliteit van de liefde openbaarde. That is all. Hij zetle de liefde om in de daad. Maar weer een citaat uit Baarda's cahier:

'Hij moet eens gezegd hebben (!!! v.d.W.): Niemand heeft groter liefde dan dat hij zijn leven inzet voor zijn vrienden' (Jh. 15. 13). Het was de inzet van zijn leven die hem aan het kruis bracht' (blz. 49).

De 'Gemeente' heef nu begrepen. dat deze historische Jezus toch niet helemaal de werkeliike Jezus kon zijn en ging achteraf deze Jezus kleuren naar eigen ideeèn. Maar. zegt Baarda. de werkelijke Jezus laat zich ook niet meer reconstrueren. De historische gegevens geven Hem. zoals Hij was. niet meer terug. Het gaat in de verkondiging niet on de Jezus. die was, mar on de Jczus, die is. De verkondiging van de kerk wil ons niet doen geloven in dat. wat het historische onderzoek uit de evangelien haalt: lezus als rabbi. wonderdoener, uniek en radicaal mens: neen. de verkondiging wil ons late geloven in de levende Héér (blz. 5()). Baarda beroept zich zelfs op het woord van 
de engel bij de opstanding: Wat zoekt gij de l.evende bij de doden? Herman Ridderbos heeft niet zonder geestigheid geschreven. dat Baarda hiermee de engel zelfs inschakelt bij de gemeente-theologen. We zou. den ook kunnen zeggen. dat Baarda een existentialistische interpretatie van het evangelie voorstaat.

\section{NIET DE LEER. MAAR DE HEER!}

De bedoeling van Baarda: de moderne mens te bewaren bij liet geloof. Die arme moderne mens heeft zo zijn bezwaren tegen de evangelien. De gemeente van vandaag heeft verder ook haar bezwaren tegen al die nieuwlichters. Welnu, hier wordt cen gemeente-cahier geboden. dat recht wil doen aan bezwaren tegen de gangbare orthodoxe opvalting. doch dat tevens de enigzins trage geneente sag wil maak', begrip wil bijbrengen voor wal de ontniythologiserende theologen zoal van de kansel den volke prediken. Het mes snijdt dus dan twee kanten: een eigentijdse geneente wordt zo gevormd, die nog werfkracht heeft ook. Mensen. die heel hun leven tegen de starre gereformeerde Schrift-opvatting zaten dan te trappen. krijgen nu te horen, dat het allentaal wel niee valt. Heus. Assen 1926. klemt niet meer. Baarda geeft trouwens op de derde baldzijde al toe. dat hij dit boekske geschreven heeft om aan de hand van de bespreking van de historiciteit van de evangeliën te pleiten voor een ruimer mogelijk. heid voor de uitleg van bijbelse verhalen (blz. 7).

Wat Baarde dus doet en doen wil is niets nieuws.

Hij borduurt verder op het oude ethische thema.

De ethischtn hebben niet alleen ten aanzien van het dogma de leer der kerk tegen de levende Heer uilgespeeld. maar zij hebben ook len aanzien van de bijbel gezegd dat het eigenlijk maar ging on een selectic van wat in de bijbel stad.

In zijn rede van $19 / 2$ heeft prof. I.ucas I.indeboom twee richlingen onder de nieuwere theologen onderscheiden:

'De eene, de modernen, die er rondweg voor uitkomen, dat zil in den Bijbel een boek zien als alle andere en in den godsdienst van Israël niet meer dan een van de voornaamste godsdiensten; de andere. de ethischen. die nog veel of weinig van de in den Bijbel verhaalde feiten als geschiedenis willen vasthouden. omolal zij 't niet missen kunnen als steunsel van hun geloof. Dic allen komen hierin overeen. dat zij niet a priori de onfeilbaarheid van de H.Schrift aannemen. en zich dus ook niet gebonden achten aan het verhaal der feiten en den samenhang der feiten en aan de dogmatische en paraenetische pragmatiek der geschiedenis en geschiedenissen, zoo als die in den Bijhel geschreven staan. (C'mira de Religionsgeschiche de Historia Sacra. De' ahsolute l'ormate voor het reche verstand en onderwiis v'an de Bijhelsche (ieschiedenis en de geschiedenis der godsdiensten. J. H. Kok. Kampen. 1912. blz. 12).

I indeboom voegde hierbij. dat beide richtingen bii alle verschillen principieel de oude paden verlaten hebben en principiecl op dezelfde 
weg wandelen en daarom in haar beschouwingen lijnrecht ingaan tegen de oude. welbeproefde meningen der christenen. Beide opvattingen noemen het immers onwetenschappelijk uit te gaan van de inspiratie en Goddelijke autoriteit van de bijbel.

Wij hebben in het werk van Baarda niets anders te zien dan een zoveelste poging om de ethische uitleg der Schrift onder 'de gereformeerde gezindte' te importeren. Niet de leer. maar de Heer! Niet de historie, maar de verkondiging! Niet de tekst van het evangelie. doch het kèrugma. de boodschap!

HOE DEZE AANVAI OP DE BETROIIWBAARHEID VAN DE SCHRIFT TFGEN TE TREDEN?

Dat Baarda in flagrante strijd met de belijdenis komt, is zonneklaar. Wij geloven zonder enige twijfeling al wat in de Schriften begrepen is, zegt art. V van de Nederlandse Geloofsbelijdenis.

Baarda wil niet van dit a priori uitgaan. Hij heeft zich een keer beroepen op art. VII. waarin staat. dat de wil Gods volkomen in de Shrift vervat is. En hij zei toen. dat dit nog niet betekende, dat de wijze. waarop die wil in verhalen verpakt was, daarom die verhalen van a tot $z$ historisch deed zijn (ik geef zijn mening hier weer met eigen worden). Doch dit is maar geknoei. Mensen. die tot zulke concessies in staat zijn, heeft de frisse 1 indeboom in zijn bovenaangehaalde rede getypeerd als 'brave modderaars'. Hier is een of-òf, een Fntweder-Oder. of de openbaring is Coddelijk en bezit de grootst mogelijke autoriteit. of we hebben hier te maken met creatieve of recreatieve producten van de menselijke geest.

Echter, met de afwijzing van de inzet van Baarda zijn we er niet.

Wij mogen ons hier niet te gauw van afmaken door te constateren: ethische benadering van de Schrift. ontmythologiserende tendenzen, enz.

Het komt mij voor, dat wij kerk noch theologie dienen. door met een radicale afuijzing te volstaan. Fr zit immers ook nog zoiets als een pastorale kant aan deze zaak. Door allerlei aanvallen op de hijbel. van Celsus. De Dagerad van vroeger of van mensen als Baarda. wordt veel stof omhoog geworpen. Fr komen mensen met werkelijke problemen! Nu kunnen we met een vlot handgebaar al die bezwaren wel weg willen werken, al roepend: leve de inspiratie! Maar dit zal niet bij ieder gelukken. Het zou de eerste keer niet zijn. dat iemand van ons of van buiten ons met een goedkoop kluitje in het riet gestuurd werd. Ik denk met name aan de al of niet studerende jeugd. Die heeft zo haar vragen. Ook al wil men geloven. daarom (of misschien wel: daarom juist) zoekt men antwoord op vragen. Er zijn verschillen in de "verwoording' van het evangelie aan te wijzen. De zg. synoptische 'evangelien' spreken anders dan dat van lohannes. Hoe moeten we daarmec aan? Welk Antwoord-1967 geven we. nu al die critiek op de bijbel loskomi? We kunnen hier niet iussende gebaren maken en weigeren op de atangevoerde al-of-niet-steekhoudende argumenten in te gaan. 
We moeten verder de mogelijkheid overwegen. dat onze gangbare uitleg van bepaalde teksten (straks hiervan een voorbeeld) soms aan critiek steun biedt of zelfs - zonder dat we het weten -.- aan Schriftcritische uitleg ontleend is. We moeten mar rondweg toegeven, dat in heel de wereld de orthodoxe leiders vaak zo overstelpt zijn met allerlei dingen. dal ze niet kunnen inga op de zaken. Men heeft van vrijzinnige kant daar wel eens attentent op gemaakt: die rechtziningen zijn eigenlijk steriel. zij kunnen geen grote theologen opleveren. die het onderzoek van de bijbel verder brengen. Nu geloof ik van deze laatste insinuatie. die een groot man van vandaag (Batt) gemaakt heeft. geen snars. Maar wij mogen geen aanleiding tot een dergelijke opmerking geven. Het is inclerdad zo. dat je om rechtzinnig geloof in de wereld te vinden vaak bij pietisten en methodisten te gast moet gaan. die tevreden zijn bij een 'eenvoudige' uitleg van de bijbel. speciaal gericht op de praktijk des levens. en zich verder om al die vrijzinnige danvallen niet al te druk maken. Ik weet dat ik generaliseer. maar ik doe dat bewust. Want het gaat me hierom: de ogen te openen voor de noodzaak om van rechtzinnige zijle op al wat zo naar voren gebracht wordt eens cen duidelijk antwoord te geven. Daar hoeven we niet bang voor te zijn. Wij hebber, een woord voor de wereld. Bovendien kon het wel eens zijn, dat bij een overzien van alle bezwaren wij aanleiding vonden om te constateren. dat een hepaalde uitleg. die wij als de gangbare in stand houden. verlaten moet worden. omdat deze geen recht van bestaan heeft en au fond koren op de molen van de vrijzinnigheid is. We moeten niet denken. dat Ciod ons die lawines op ons dak zendt. opdat we maar als de gerusten in Sion leven zouden. In deze benauwing -- hoe is anders de opleving van het ethische modernisme in 'gereformeerde' kring te typeren? ligt voor ons een opdracht.

Van het zien van die opdracht merkt men niet veel als de dominees wel mooie plaatjes draaien. maar tegelijk als het over de bijbel gaat. bij al hun rechtzinnigheid zeggen: daar zit ik eigenlijk niet in. 7e mogen best een mooie gramofoonplaal draaien. als deze hen dan maar inspireert on aan de slàg te gaan. Anders is die gramofoonplaat maar een slaapkussen. die hun nog minder de benauwing van vandaag laat zien. Niets tegen buitenlandse reizen. Maar laat men die gebruiken om de situatie in kerkelijk opzicht in de wereld eens te zien: lege kerken. Jominees die ambtenaar zijn en een theologische wetenschap. die door staatsubsidie aan de gang gehouden wordt en tevens dient tot afbraak van het christendom.

Maar ja, als men het leven in vakjes verdeelt, dan gaan de ogen toe voor de grote benauwdheid. geniet men zijn plaatje. houdt zijn vacantietie. houdt ook zijn preekje. en daarbuiten is de boze wereld. I.ief (kerkelijk) vaderland kan rustig zıin. Doch op deze wijze kweekt men een weerloos volk, laat alle problemen aan specialisten over, en vlucht in vrome frasen. Dat daardoor kwesties geschápen worden. dat daardoor ook velen afgestoten worden. dat 7o de strijd niet gestreden wordt en de vrucht van de benauwdheid niet genoten wordt. kan zo evident zijn. 
Daarom wil ik hier met grote ernst pleiten voor een werkelijk ingaan op dat. wat vijanden van de autoriteit van de Schrift naar voren brengen. Anders worden we inderdaad steriel. En God zal een dergelijke zelfvoldaanheid zeker straffen. Wij hebben niet de roeping naar de ander te kijken. of hij voor ons wapens zal smeden. Wij hebhen op te staan tot de strijd. Waar is ons "Cahier voor de Genseente'. dal de aanval inzet? Maar neen. we teren liever op oude roem en halen onze schouders op: die aan de overkant zijn fout. maar ik zit er eigenlijk ook niet erg in.

Hebben we dan geen Woord voor de wereld? Hebben we dan niets te zeggen voor hen die 'lijden aan de tijd'. die gebukt gaan onder de aanvallen op de Schrift'?

\section{WAAR BEGINT DE HISTORISCHE ONBETROUWBAARHEID?}

Baarda geeft in zijn boekje verschillende overzichten en schen a's waaruit de historische onbetrouwbaarheid van de evangelien blijken zou. Hij wijst op de geheel andere "stof" van het evangelie naali Johannes vergeleken met die van de andere drie "evangeliën'. Hij konı zelfs tot de boude uitspraak. dat Iohannes Galilea te kort doet (blz. 2(1)! Hij wijst op de verschillende chronologic. die er volgens hem hestaat. De dagen van het lijdensverhaal 'kloppen' volgens hen niet. als men het relaas van de synoptische evangelien vergelijkt. Er zijn verschillende reisschenia's. Menig woord is in een enigzins andere versie overgeleverd. De verhalen van het gebeurde na die opstanding zijn wel van grote gevarieerdheid.

$\mathrm{Nu}$ willen we beginnen met de erkenning. dat we in de vier 'evangeliën' niet vier boeken vinden. die als druppels water op elkaar gelijken. $\mathrm{Er}$ is verschil in stof, in compositie. enz. l.ucas had weer een ander doel Jan Johannes. Doch is hier reden on de alarmklok te luiden en te concluderen tot historische onbetrouwbaarheid? Baarda gaat uit van dat. wat hij bewijzen moet. We willen straks via enkele voorbeelden duidelijk maken. dat er geen enkele reden is on de variaties in compositie enz. als argument te gebruiken voor de erkenning van een spelen van de "evangelisten" met de historie ten behoeve van de opzet van hun boek, als schreven ze een stichtelijke roman.

Toe te geven is, dat de tekst van overgeleverde Woorden van lezus kleine verschillen vertoont bij de "evangelisten'. Maar is hier sprake van historische onbetrouwbaarheid? Hebben we niet eerder te naken met de kwestie van vertalen? Allereerste zijn de Woorden van Jezus in het aramees gesproken. En mogelijk eerst nog wel in het aramees opgeschreven ooh. Een ieder heeft. zegt Papias. de in het hebreeuws (aramees) door Mattheus geschreven Woorden van Jezus vertaald. zo goed hij kon. I ucas. die zijn boek opdroeg aan de hoogedele Theofilus hecf in zijn redactie zeker rekening gehouden met de kennisinhoud en achtergrond van Theofilus. Maar kunnen we nu het feit. dat l ucas hier en daar een parafrase gaf. gebruiken voor de stelling: het evangelie is onhetrouubatar" Kunnen we zeggen. dat 
L.ucas in verband met het kader, waarin hij de stof plaatste, deze omgevormd heeft om aan het gestelde doel te beantwoorden?

Met enkele voorbeelden willen we dit nader verduidelijken.

DE (iRIIWEI. DER VERWOESTING.

Baarda plaatst de teksten van Mattheus/Marcus èn die van l.ucas over de 'gruwel der verwoesting' naast elkaar en vraagt dan: wat heeft Jezus gezegd? (blz. 39). Hij meent ook, dat er veel voor te zeggen is. dat lucas de apocalyptische woorden van .lezus een historiserende exegese gegeven heeft, deze geactualiseerd heeft (de vreemde termen zijn van Baarda zelf bij zijn boek voor de gemeente). L.ucas zou dus onder indruk van de verwoesting van Jerusalem door de romeinen, in verband met wat er gebeur was, de Woorden van Jezus wat historisch bijgekleurd hebben; hij zou als gevolg van de vervulling van de profetie over de gruwel der verwoesting. Jezus woorden in de mond gelegd hebben. die Hij eigenlijk niet gezegd heeft. maar die in die dagen het evangelie een actuele kleur gaven. Zoiets mag men van Baarda geen vroom bedrog noemen; l ucas zou door deze actuele kleur laten uitkomen, hoe onbedrieglijk Jezus Woorden waren (blz. 82).

Voor een betere beoordeling van dit alles geven we eerste de teksten over de gruwel der verwoesting weer volgens de veretaling van Baarda:

MARCUS (Mattheus)

Wanneer gij echter (Mt. dan) ziet de gruwel der lerwosting. (Mt: waarvan door de profeet Daniel gesproken is) staande waar hij niet hoort (Mt: staande op eer heilige plaats) - wie het leest. lette er op -.. laten dan wie in Judea zijn naw de hergen vluchien.

Wie op het dak is, ga niet naar beneden ( $M k$ : èn ga niet naar binnen) om iets ( $\mathrm{M} k$ : de dingen) uit zijn huis mede te nemen. en wie op de akker is. kere niet terug om zijn kleed mede te nemen.

\section{LUCAS}

Wunner ge echter ziet lerusa. len omsingeld door legerkampen. weet dan dat nabij is zijn verwoesting.

I.uten dan wie in Judea zijn naur de hergen viluchten. en dic binnen in de (stad) zijn. laten zij de wijk nemen (vgl. 17, 3la), en die op de landerijen zijn. laten zij er niet binnengaan (vgl. 17, $31 \mathrm{lb}$.

Doorgaans wordt bij rechts en links de uitleg gegeven. dat de gruwel van de verwoesting de verovering van Jerusalem door de romeinen is. Men heeft. zoals onk Baarda doet. aan de uitdrukking van l ucas allerlei consequenties verbonden. We zouden I ucas' woordkeuze kunnen opmaken. dat Lucas achteraf na 70 in het licht van de vervulling van Jezus' Woorden precies omschreven heefı wàt die gruwel der verwoesting nu eigenlijk was. Hierbij heeft ook de tekts van L.ucas 19:43. 44 een rol gespecld. Dáár zegt Jezus inderdaad. dat de Romeinen Jerusalem zullen belegeren. schansen zullen opwerpen. enz.

Maar wat zegt Jezus in I ucas 21? 
Hier wordt het klokkesein gegeven aan de inwoners van Jerusalem. die Jezus belijden, on uit de stad te vluchten, of als zij op de landerijen zijn, direct de wijk te nemen.

Het kom me voor. dat studeerkamergeleerdheid --- net als bij de ezels van de intocht, waarover later -- een belangrijke rol gespeeld heeft.

Men denke zich de situatie eens in:

Het romeinse leger heeft Jerusalen omsingeld. Ilit Flavius Josefus weten we. dat Vespasianus een tactiek van de verschroeide aarde heeft tocgepast. en dat Titus de tuinen om Jerusalem liet egaliseren om schootsveld te krijgen, net zoals het nederlandsc leger dat deed bv. rondom Amersfoort in de meidagen van 1940.

Het is in het oosten zo. dat men vaak met hele families tijdens de oogst in de zomer buiten. op de akker woont. Ik heb dat dit jaar nog in Syrië gezien. De bewoners van Jerusalem zullen dat ook wel gedaan hebben: volkstuintjes! INDIEN Lucas nu achteraf de Woorden van Jezus eens op zijn manier cen bepaalde actualisering gegeven had, zou hij dan aan Theofilus. die waarschijnlijk als hoge ambtenaar heus wel van de militaire acties iets af wist. de voorstelling gegeven hebben. dat Jezus geadviseerd had NADAT JERI'SAI.EM OMSINGEL.D WAS uit de stad te vluchten en de volkstuintjes en landerijen te verlaten????

Gelove. wie het geloven kan.

Men leze Flavius Josefus, die heus niet zoveel nonsens ten beste geeft als men wel eens gedacht heeft. er maar eens op na. Alleen studeerkamerexegese kan Jezus" Woorden als den advies on NA de omsingeling (die een kaalstropen van de omgeving. omhakken van olijfbomen enz. inhield!) de stad te verlaten. interpreteren.

Hoe mosten we Jezus" Woorden dan lezen?

Wel. we moeten crvan uitgaan. dat Mattheus met zijn gruwel der verwoesting en Lucas met zijn ontringd-zijn-van-Jerusalem-door-legerkampen (legers) HETZELFDE bedoelen. Het gaat hier om een gruwel in de heilige plaats. Een blik op de kaart van Jerusalem leert ons. dat de heilige plaats. de tempel. tevens aan twee zijden afgegrensd werd door Jerusalems muren. De joden hebben zich vóor de komst der romeinen in die tempel verschanst. Men leze alweer Flavius Josefus. die onze oude vaderen beter kenden dan wij.

De jollen hebben door hun zingen van: Jerusalem-gaat-nooir. verloren! de heilige plaats ontheiligd. De kanonnen (katapulten) stonden er opgesteld. Waarnice zij ook elkaar bestreden. Voor de christenen uit de joden zou dit het signaal zijn. dat Jerusalem verlaten mosst worden. Theofilus, die warschijnlijk een Godvrezende was. mosst het good weten. dat Jezus zelf het uur van de radicale breuk van $(j o x l$ met het centrum van Israel aanwijst. Dit zal ook ludea raken. En daarom: naar de bergen. Toen ik dit jaar op 5 junic. onbewust van het feit. dat de oorlog uitgebroken was. Syrië hinnenkwam. zei een vrouw in Damascus tegen me: "Weet u het niet" Er is oorlog en alle mensen vluchten naar de bergen." 7o handelt men in 
dagen van acuut gevaar: de israeli's waren trouwens de hele dag in de lucht.

We hebben hier een geval. waar m.i. de exegese zich moet herzien. omdat inderdaad bij een volgen van de voorstelling. die doorgaans gegeven werd, aan Schriftcritische tendenzen voet gegeven wordl. Bovendien heeft men dan geen oog voor de pointe van Jezus' Woord. Hij wijst hier de gruwel aan (verg. Ez. 8. Openb. 17) van de afval van het bondsvolk. die de climax bereikt heeft. (jaat uit van haar. Mijn volk! Mattheus/Marcus è L_ucas zijn volkomen in overeensten.ming. Men kan hoogstens zeggen. dat Lucas ten behoeve van Theofilus een parafrase gegeven heeft. Dal hij dit deed, terugblikkend op de afloop. is helemaal niet nodig aan te nemen. Het is voor mij de vraag, of we één nieuwtestamentisch boek later dan 70 moeten dateren. Lucas heeft zijn evangelie welbewust in dienst gesteld van de oproep tot vrijmaking van de synagoge des satans. Voor Theofilus was kennelijk het grote probleem: moet ik nu weer van kerk veranderen? Heeft God Zijn volk verstoten? Jezus' eigen Woorden geven op deze vraa: een duidelijk antwoord. Gruwel der verwoesting in de Heilige Plaats. Dat kon iedere jodenchristen. die Daniel kende. verstaan. Jerusalem met een ring van versterkingen om zich heen. - dat kon Theofilus begrijpen. Als hij $66-70$ nog meegemaakt heeft. is het bericht: Jerusalem versterkı zich! zeer duidelijk geweest. Oude profetieën èn Jezus" dreigende Woorden zouden in vervulling gaan en het gericht over het zich verhardend bondsvolk naakte.

Historische onbetrouwbaarheid van Jezus" Woorden?

Dat zij verre!

\section{DE EZ.EL.S BIJ DE INTOCHT.}

Baarda laat in zijn boekje. evenals hij dat gedaan heeft in zijn artikel tegen Arntzen, weer de ezels bij de intocht opdraven. Wij zijn daar destijds op ingegaan en hebben pogen aan te tonen. dat hier ook van studeerkamer-theologie sprake was. $\mathrm{Nu}$ Baarde hier weer de historische betrouwbaarheid van het evangelie dantast door erop te wijzen. dat Mattheus van twee en de andere evangeliën van één ezel spreken. de volgende opmerkingen:

a. Baarde stelt (blz. 57), dat het DIIIDEIJIK is. DAT HIER DF: GESCHIFDENIS DOOR DE PROFETIE VERVORMD IS. He: staat er letterlijk: VER-vormd. Niet eens HER-vormd. maar vervormd. Vervormen is iets een andere vorm geven. Als ik uit leem een beker vorm, kan ik het leem daarna weer incenslatan en er een ander voorwerp van kneden. Mattheus heeft volgens Baarda onder invloed van de profetie van Zacharia 9:9 van iwee ezels gesproken. Hij heeft dus, laten we dat maar ronduit zeggen. er een ezel bijgefantaseerd.

Baarda meent blijkbaar, dat de mensen in die dagen geen herinnering meer hadden. In het hoofd van niet één getuige is het blijkbaar opgekomen. en Mattheus heeft dat ook niet gevreesd. dat er maar van één gesproken kon worden. Dat was men in 
de oudchristelijke gemeente zo gewoon. Men vormde de historie om on deze op de profetie te laten kloppen. De lieve gemeente heeft zo'n bijbel. waar fantasiën in staan. die dankbaar geslikt zijn door mensen. die heel goed wisten, dat het eigenlijk anders was dan er stond. Gelove wie het geloven wil.

b. Baarda heeft blijkbaar kennis genomen van het argument. dat het moederdier wel eens meegelopen kon hebben. De jonge ezel. waarop Jezus reed. was onbereden. Mensen waren in de weer met kleden en palmlakken. $\mathrm{Er}$ was een situatie. die nu niet bepaald bevorderlijk was voor de ecrste rijles. In zo'n geval maakt een voorgaand moederdier de jonge ezel meegaand. Wie wat van ezels afweet. zal dit bevestigen. Een jonge ezel kan behoorlijk bokkesprongen maken en pogen er tussen uit te gaan. Ik heb nog niet zolang geleden meegeholpen om op de kade van Patmos zo'n dartelende jonge ezel ligen te houden. Maar Baarda verwerpt hier de boeren-exegese. Men kan volgens hen niet zeggen, dal het moederdier meeliep. want als er voor Mattheus één ding belangrijk was. dan was het wel de ezel. die steeds voorop genoemd wordt, en niet het veulen. Hij zegt. dat het ONWEERI.EGBAAR is, dat de profetie lange tijd vormend ingewerkt heeft op de weergave van de verhalen.

Onweerlegbaar. . Matar is dit zo' Waarom hier niet eens ingegaan op de noolzakelijke roorgamg van de ezelin? Men krijgt het idee. dat koste wat het kost de gemeente moet aan. vaarden, dat onweerlegbaar Mattheus verhalen uit zijn evange. listenduim gezogen heeft. En dat onweerlegbaar blijken moet. dat de studeerkamer-los-van-de-boerenpraktijk Baarda's exegese beheerst.

c. Baarda maakt zich sterk door te zeggen. dat er staat: En Hij zat op hen (ik heb hier de hoofdletter gebruikt: Baarda schrijft: hij). Nu verlaalt de Nieuwe V'ertaling: Hij ging daarop zitten. In de vorige zin is sprake van klederen. die op de ezelin en haar veulen gelegd werden. Men kan het zo opvatten. dat Jezus op die klederen ging zitten. De klederen op het moederdier zouden dan het triunfale accentueren. Overwinnaars legden wel op de rijdieren de klederen van hun vijanden.

Doch ook als men het "op hen" op die beide ezels wil laten slaan. en daar is misschien wel wat voor te zeggen. kan hiermee gezegl zijn. dat lezus eerst op het noederdier en later op het veulen gereden heeft. Men kan verder opmerken. dat er tekstoverleveringen zijn. waarin gesproken wordt van: zal op hem $(\mathrm{nl}$. het veulen).

Maar in elk geval is er geen reden om hier van vervorming van het evangelic te spreken.

d. Baarda wijst er op. dat lohannes zegt. dat Jezus een ezeltic $10 \mathrm{ml}$. terwijl bij de anderen staat. dat de discipelen het vinden. I:en opmerkelijk verschil. zegl Baarda.

Maar zelf vermeldt hij in zijn overzicht. dat Jezus zelf het czeltje laat hálen. Achter het vinden van de discipelen la: het 
vinden van lezus. $\mathrm{Er}$ is geen enkcle reden voor Baarda $\mathrm{um}$ haast triomfantelijk uit te roepen: welke versie heeft nu aanspralak op het etiket betrouwbaar'? (verg. hlz. 30).

\section{VERSCHII.LENDE CHRONOI OGIE VAN DE I.IJDENSWEEK?}

Baarda zet, evenals in het artikel tegen Arntzen. de weergave van de eerste drie dagen van de lijdensweek bij de eerste drie evangelien naast elkaar. Hij constateert dan verschillen. Mattheus zou de tempelreiniging op de eerste dag plaatsen en Marcus op de tweede dag na de intocht.

De zaak is echter deze. dat Mattheus in verband met het doel van zijn boek direct de tempelreiniging vertelt. Er staat nergens in Mattheus. dat Jezus de eerste dag, de dag van de intocht. de tempel reinigde. Er staat alleen: En Jezus ging de tempel binnen. Matthers ordent sukelijk. Hij geeft ook het gesprek na de verdorring van de vijgeboom direct na de vermelding van de vloek en de verdorring. We hebben geen enkele reden aan Mattheus hier een precies-chronologisch schema op te dringen.

Marcus echter ordent niet zakelijk. maar volgt de kalender:

eerste dag: intocht en inspectic van de tempel;

tweede dag: vloek vijgeboom en reiniging van de tempel (let op de volgorde!);

derde dag: gesprek naar aanleiding van de verdorring van de vijgeboom.

Wij komen helemaal niet met Baarda (blz. 25) voor de vraag te staan wie van de getuigen een minder betrouwbare weergave van de feiten geeft. Baarda heeft geen rekening gehouden met de verschil. lende mogelijkhede bij een vertelling. Hij heeft een westers tijdsschema (echt studeerkamerwerk!) weer opgedrongen aan de tekst. $\mathrm{Hij}_{\mathrm{j}}$ heeft geen oog voor hel feit. dat de bijbel meermalen. bv. in Koningen, miet precies volgens ons tijdsschema spreekt.

In de grond is de methode waarop Baarda met bijbelse teksten omspringt Joor en door onwetenschappelijk. hoe wetenschappeijjk zijn papegaaientaal (want hij praal de Schrift-critici van verleden en heden na) misschien ook voor de goegemeente moge schijnen.

\section{HET EVANGEI.IE NAAR JOHANNES.}

Volgens Baarda was Johannes een redactor. die zijn bock met hehulp van verschillende bronnen samenstelde (blz. 73). Hij heeft waarschijnlijk zijn bock laat geschreven (in de negentiger jaren) en kende. aldus Baarda, de andere evangelien niet. Voor het vierde evangelie ligt het centrum van Jezus' werk in Judea (blz. 14). Iohannes werkt via een drie-jaar-schema. de andere evangelien suggereren cen éen-jaar-schema. Johannes doet (jalilea te kort. Mattheus 23:37 suggereert een grotere activiteit van Jezus (hoe dikwijls...). dan de eerste drie evangeliën melden. De verslagen van de evangelisten kunnen niet geharmoniseerd worden. aldus Baarda. Fen diffuus beeld blijft achter (blz. 20). 
Baarda deelt ons verder mede. dat er in wat we lezen in Johannes iets is, dat zweent naar mystiek. 'misschien moeten we wel zeggen: naar gnostiek' (blz. 74). Hij vraagt: klinkt in de reproductie van de woorden van Jezus in Johannes wellicht iets van het religicuze leef. klimaat mee, waarin de gemeente waartoe de redactor behoorde Jezus beleed en zijn woorden bewaarde'” (blz. 74): op blz. 75 wordt deze vraag nog eens in andere woorden gesteld.

Baarda vraagt verder. of het niet mogelijk is. dat Johannes in liet kader van zijn evangelie ons de woorden van de Opgestane meegeeft. ZOAI.S DIE DOOR PROFETEN IN ZIJN GEMEENTE WAREN VERKONDIGD (blz. 75). Johannes zou dus eigenlijk "preken' van oudchristelijke dominees bevatten. maar geen originele Woorden van Jezus: daar komt het zo ongeveer wel op neer. Preken met een bijsmaakje van mystick en gnostiek. Aan de randen van de traditie sprak het volksverhaal. het gerucht en soms de eigen impressie van de overleveraars mee. Hoe zullen redaktoren dat ooit geschift hebben'. . Tenslotte leefden zij in een gemeente. waarin de profetie in naam van de levende Heer gestalte gaf aan zijn woorden. (blz. 76; men leze de twee laatste woorden aldus: Zijn Woorden).

Het kan voor ieder duidelijk zijn. dat Baarda hier uitgaat van allerlei stellingen, die eerst nog maar eens bewezen moeten worden. Toch willen we ook hier de opmerking maken. dat de 'rechtzinnige' exegese zich al te lang door allerlei beweringen, afkonstig uit de vrijzinnige hock. op een sleeptouw heeft laten nemen. voor wat het evangelic naar Johannes aangaat. Hier zal ijverig gestudeerd moeten worden, om het vernis. dat in de loop der jaren over Johannes is gestreken door allerlei 'ganghare' canoniek. weer te verwijderen.

De traditie zègt wel. dat het Johannes-evangelie zo laat is. maar is dit te aanvaarden? We geloven, dat deze overlevering op vrij losse schroeven staat.

Verder: het is wel merkwaardig. dat Baarda de overlevering. dat het evangelic door Johannes geschreven is (da apostel. dien Jezus: liefhad) niet aanvaardt. terwijl het evangelie zelf daartoe loch alle. alle aanleiding geeft. Ook zonder dic overlevering moet de conclusic getrokken worden: hier is Johannes de alteur (wij laten hier het optreden van een mogelijke secretaris of vertaler buiten besprekingl.

$\mathrm{Nu}$ dient vanuit de aanvaarding van Johannes. de apostel. als auteur. de canoniek en exegese m.i. te komen tot een nadere toatsing van de "gangbare mening". Wanneer we het bseld van een late editie eens laten vallen, dan gaan onze ogen onen voor de mogelijkheid. dat Johannes zeer vroeg alles te boek gesteld hecît en in elk geval in zijn prediking zeer vroeg zijn weergave van de feiten in cen stereotipe vorm gegoten heeft. Het is volgens mijn mening helemaal niet uitgesloten. dat Johannes 'preekverslagen' van Jezus' redevoeringen heeft gemaakt. of een dagboek heeft bijgehouden. Ziin weergave van de feiten. d: discussies, de verhoren is weergaloos levendig en precies. (jod werkt 
ook in de middellijke weg en we verwerpen de mechanische inspiratie. De dialogen in Johannes" boek komen als "t ware heet van de naall.

Johannes is lange tijd na pinkster in Jerusalem werkzaam geweest. Hij heeft stellig in zijn prediking Jezus ' Woorden en daden te Jerusalem weergegeven. Baarda wekt de indruk, dat hij aanneent. dat het evangelie préken van oud-christelijke 'dominees' over Jezus weergeeft. waarbij zij dan Jezus hun eigen meditaties (en dan nog wel met een mystiek of gnostisch luchtje eraan!) in de mond leggen. In plaats van dit iroom hedrog te aanvaarden, zouden we toch met de opmerking van Batarda onze winst willen doen en het zo stellen: Johannes geeft een soort hundel van preken van Jezus. Daarin streeft hij zijn eigen doel na. hij wil de kerk afgrenzen van de synagoge des satans en tegelijk leden van de laatste nog oproepen tot bekering!

Hierbij is de spits op Jerusalem gericht.

In verband daarmee verwaarloost Johannes (jalilea niet (Joh. 6). Maar wel laat hij in verband met het doel van zijn bock het tijilsschema waarin Jezus optrad zeer duidelijk uitkomen. Hij laat zien. hoe Jezus optrad (net als de oude profeten) tijdens lsraels grote feesten. Jezus is het Paraslam. Hij reinigt de tempel tijdens ean pausfeest. Later bezoekt Hij een paurfeest niet (Joh. 6). Maar op het laatste parafeest is $\mathrm{Hij}$ weer present en sterft dan als Gods offerlam. Dat Hij tijdens een loofhuttenfeest in het begin niet aanwezig wilde zijn (Joh. 7), vindt ook zijn verklaring in de wil op een paasfeest te sterven: ,de ure' is dan aangebroken. Wel laat Johannes uitkomen, hoe Jezus zich als de Vervuller van het loofhuttenfeest heeft bekend gemaakt (water des levens, licht der wereld. der eeuw). Johannes geeft dus Jezus' gebeuren weer in het Joor Hemzelf gekozen festale schema om Jezus als de grote Vervuller aan te duiden.

Bij nader onderzoek blijkt Johannes' taal door en Joor iools. wil men: aramees. Dat iemand, die waarschijnlijk een neef van Jezus was, de Woorden van de Heiland goed kon weergeven, is voor de hand liggend. Terwijl de andere evangelien veelal spreuken. excerpten van Woorden weergeven. vinden we bij Johannes verslagen van preken en dialogen. En we haasten ons erbij te voegen: Jezus" Woorden verraden geen grieks klimaat, maar grijpen keer op keer - de exegese heeft dit punt al te zeer verwaarloosd - terug naar het Oude Testament. Daarom vinden we hier geen mystiek of gnostiek klimaat. dat uit de gemeente van de heer relactor afkomstig zou zijn. En evenmin vinden wie hier een bundel historischen Studiën en Fantasiën.

\section{SL.ECHTS ÉEN TEMPELREINIGING;}

Balarda brenet ook het feit ter sprake, dat Johannes de tempelreiniging bij zijn cerste paasfeest onderbrengt. terwijl de andere evangeliën het verhaal vlak voor het paasfeest van Iczus' kruisiging invoegen' (blz. 23). 
Dit moet weer als argument voor de historische of chronologische onbetrouwbaarheid van het Nieuwe Testament dienen. $\mathrm{Er}$ is iets met de chronologie van Johannes aan de hand. aldus Baarda; tenminste: we hebben te gereder aanleiding het vermoeden uit ie spreker. dat dit zo is.

Inderdaad heeft de plaatsing van de tempelreiniging steeds voor vragen gesteld. Sommigen hebben uigesproken. dat lohannes deze thematisch voorop gezet heeft. Deze oplossing is niet te aanvaarden. Johannes geeft ons een zeer doorzichtig tijdsschenia; zijn evangelie is geborduurd op het stramien van Israels hoge feesten. Lucas. ja. hij zet de prediking in de synagoge thematisch voorop. Doch Iohannes. de getuige, ordent naar de tijd, hij die de klokhestand zo goed wist te vernielden.

Daarom zijn er TWEE tempelreinigingen aan te nemen. En als we er op letten. dat de andere evangelien wel het woord vermelden. Jal Jezus bij de eerste tempelreiniging uitsprak (Breekt deze tempel af ...). maar hiervan gewagen bij het proces van Jezus en niet bij HUN verhaal over de tempelreiniging. dan wordt het duidelijk. dat zij een rweede tempelreiniging weergeven. Als Jezus dit woord bij de laatste tempelreiniging zou hebben gesproken. zouden de vaise getuigen wel eenstemnig geweest zijn. Maar het was al twee jaar geleden, dat Jezus dit woord liet horen. 7e konden het zich niet precies meer herinneren en spraken elkaar tegen.

Daarom: twee tempelreinigingen. De massale verkoop van paaslammeren vond natuurlijk tijdens het paasfeest plaats. Zou de Here Jezus naar hel paasfeest zijn gegaan. dat Joh. 6 vermeldt. dan zouden er drie tempelreinigingen zijn geweest. want deze gruwel in de Heilige Plaats kon Jezus niet verdragen. Maar Hij is toen niet opgegaan. en heeft volstaan met het houden van een paspreek in Gialilea. omdal toen Zijn ure nog niet gekomen was.

We zien weer. er is geen enkele reden om ons zenuwachtig te iaten maken door allerlei beweringen van Schriftcritici. Tegelijk is er alle reden on ons af te vragen. of we. bv. bij ons vertellen. het feit van de twee tempslreinigingen voldoende gehonoreerd hebben. Hebben we dit punt vaak niet verlegen on de achtergrond geschoven. ondal we er toch eigenlijk geen raal mee wisten? Zijn we wel voldoende ingegaan op de eigen structuur van lohannes boek? Juist als een door de aanvaarding van de historische betrouwbaarheid der Schrift bepaalde stijl ons onitbreekt grijpt de Schriftcritiek de kansen. DU IS

Batarda gebruikt op blz. 36 het woordje dus' driemaal achter elkaar. Dit woordjie schijnt net als .ergens nogal frequent te worden in het huidige nederlands; we zijn een volk van Van der Dussens geworden. zegl men.

lit het bovenstaande kan echter blijken, dat we met menig dus' van Baarda niet accoord gaan. Natuurlijk zou er op nog meer voorbeclden. dic hij bozigt. in te gaan zijn. We denken bv. aan wat hij zegt over de opstandingsverhalen en in dit verband aan wat (destijds) Ds. I. van Bruggen hierover in De Reformatie schreef. 
Doch we menen, dat uit wat naar voren gekomen is, duidelijk blijkt. dat Baarda met spek naar de evangeliën schiet. Wij hopen ook, dat door wat we schreven ingezien wordt. dat het helemaal niet nodig is zich bij deze aanval in zijn geloof aan het vaste Woord bedreigd te voelen. De Schrift verdedigt zichzelf, zoals zij zichzelf ook uitlegt. Wij worden echter wel geroepen om de Schrift te laten spreken en alle hens aan het dek te roepen om het kerkschip te bevrijden van alle vuil en roest, die zich vanuit het Schriftcritische kamp ongemerkt daar genesteld hebben. In hel onderzoek der Schriften. het slechts door de Schriften bevooroordeclde onderzoek, ligt groot loon.

\section{OVERHEERSING VAN HET EXISTENTIAI.ISTISCHE „EVANGELIE'}

In Novum Testamentum VII, 1966, schreef H. M. Bolkestein een artikel over de synoptische evangeliën als leerstof. Daarin wees hij op het feit. dat in Nederland doorgaans in catechisatieboekjes de geschiedenissen uit de bijbel op een oncritische manier worden doorgegeven. Naief wordt, aldus de schrijver, ervan uitgegaan, dat alles wat in de evangelien staat even zeker is als bv. de opgang en ondergang van Napoleon.

$\mathrm{H}_{\mathrm{ij}}$ pleit er dan voor, dat de nieuwere inzichten eindelijk eens moeten doordringen in de catechisatie. De evangeliën bieden immers geen weergave van nuchtere feiten. zij zijn slechts een verkondiging van wat Jezus voor ons IS. niet van wat Hij WAS. TTussen haakjes: Baarda gebruikt dezelfue termen!). Het evangelie is een kerugma. waarvoor de vorm van een historisch-onbetrouwbare geschiedenis gekozen is. De story van de vermenigvuldiging Jer broden wil alleen maar zeggen, dat de levende Heiland vandaag nog voor ons zorgt.

Vroegere preken over een wonder van Jezus hadden vaak deze verdeling:

1. de omstandigheden van dit wonderwerk:

2. het feit van dit wonderwerk:

3 de troost van dit wonderwerk.

Blijkbaar kunnen we volgens de nieuwe beschouwing de eerste twee punten wel weglaten, omdat het niet over een werkelijke geschiedenis gaat. Trouwens punt 3 is ook aanvechtbaar. want we zouden hier slechts te maken hebben met een verhaaltic. de troost van een verhaaltje, en niet met de troost van een werktlijk geschied wonder.

Er valt mee te rekenen, dat we straks kinderbiibels kriigen. die de invloed van de ontmythologisering ondergaan hebben. De jeugd op de lagere en middelbare scholen krijgt met deze dingen te maken. Toen Baarda in het Geref. Weekblad critiek kreeg van prof. Herman Ridderbos, werd de laatste onmiddellijk aangevallen door dr. C. Augustiin, die als ik juist ben evenals drs Baarda aan de Vrije Universiteit verbonden is en wel aangesteld, speciaul voor opleiding tot het leraurschap) in het goxlsdienstonderwij. (aldus JaJarbonek 1965). 
Er zullen leraren komen (of ze zijn er al), die Bultmann. Ebeling. Fuchs en anderen naspreken. en zo de jeugd beinvloeden. En niemand make zich de illusie, dat dit enkel en alleen in Duitsland en Nederland zal geschieden!

Hier klemt de roeping om waar het mogelijk is de waarschuwende stem tegen dit alles te laten horen. Dit houdt ook in. dat leerboeken voor de jeugd eveneens tegen deze gevaren moeten waarschuwen! We zıjn vandaag niet klaar met het doorgeven van wat door de ouden gezegd is. maar we moeten ons ten overstaan van de jeugd welbewust keren tegen wat door de nieuweren gezegd wordt. Hier geldt het op te worstelen tegen de valse gerustheid, die geen striid aandurft. Wanneer de huidige generatie niet gewaarschuwd wordt. zal zij als een gemakkelijke prooi in handen vallen van hen. die het existentialistisch evangelie verkondigen. Velen zijn meegesleurd. omdat zij slechts oude loopjes geleerd hadden en geen verdedigingsoorlog. laat staan cen aanvalsoorlog, konden voeren.

C. VAN DER WAAI.

Pretoria, 1967. 